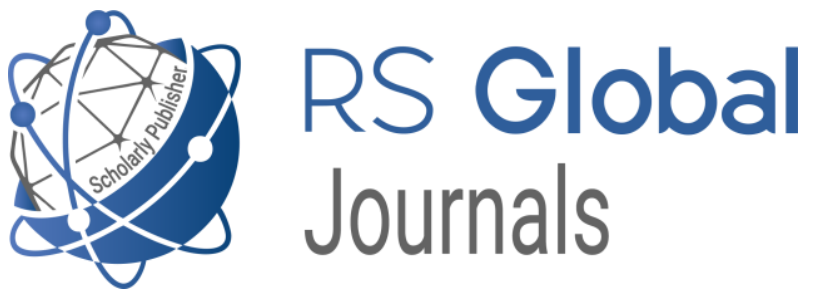

Scholarly Publisher

RS Global Sp. z O.O.

ISNI: 0000000484952390

Dolna 17, Warsaw, Poland 00-773

Tel: +48226022703

Email: editorial_office@rsglobal.pl

JOURNAL International Journal of Innovative Technologies in Social Science

p-ISSN $2544-9338$

e-ISSN

2544-9435

PUBLISHER

RS Global Sp. z O.O., Poland

ARTICLE TITLE

ПЕРСПЕКТИВИ ІНСТИТУЦІЙНОГО РОЗВИТКУ

НЕУРЯДОВОГО СЕКТОРУ: АНАЛІЗ ПРОЕКТУ

НАЦІОНАЛЬНОЇ СТРАТЕГІЇ РОЗВИТКУ ІГС

$\operatorname{AUTHOR}(\mathbf{S})$

Дмитренко Олена Анатоліївна

Dmytrenko Olena. (2020) Prospects of Institutional Development of the Non-Governmental Sector: Analysis of the Draft National

ARTICLE INFO Strategy for CSI Development. International Journal of Innovative Technologies in Social Science. 7(28). doi:

10.31435/rsglobal_ijitss/30122020/7232

DOI

https://doi.org/10.31435/rsglobal_ijitss/30122020/7232

RECEIVED

17 September 2020

ACCEPTED

03 November 2020

PUBLISHED

08 November 2020

LICENSE

This work is licensed under a Creative Commons Attribution

4.0 International License.

(C) The author(s) 2020. This publication is an open access article. 


\title{
ПЕРСПЕКТИВИ ІНСТИТУЦІЙНОГО РОЗВИТКУ НЕУРЯДОВОГО СЕКТОРУ: АНАЛІЗ ПРОЕКТУ НАЦІОНАЛЬНОЇ СТРАТЕГІї РОЗВИТКУ ІГС
}

\author{
Дмитренко Олена Анатоліївна, \\ Магістр політологї, аспірант Інституту політичних та етнонаціональних досліджень \\ ім. І.Ф. Кураса Національної академії наук Украӥни, м. Київ, Україна, \\ ORCID ID: https://orcid.org/0000-0003-1360-9395
}

DOI: https://doi.org/10.31435/rsglobal_ijitss/30122020/7232

\section{ARTICLE INFO}

Received 17 September 2020 Accepted 03 November 2020

Published 08 November 2020

\section{KEYWORDS}

civil society institute,

civil society,

institutionalization,

non-governmental sector,

financial capacity of NGOs, organizational development of NGOs.

\begin{abstract}
This study is devoted to the analysis of the draft National Strategy for the Development of Civil Society Institutions in Ukraine for 2021-2025. The developed document has already been presented to the public and is being discussed in the regions of the country. A positive trend in this aspect is the procedure of developing and harmonizing the content of the Strategy with the involvement of a wide range of stakeholders. According to the results of the analysis, we found that the strategic directions of civil society development in the country have not changed since 2016, although the new Strategy sets clearer goals. Dividing the tasks of the Strategy by the nature of their implementation, we found that the greatest efforts over the next five years will be aimed at improving the regulatory and legal support of CSOs (37.9\% of tasks). The crosscutting theme of the whole document was the development of the foundations for the crystallization of the NGOs into a full-fledged economic player and bringing the activities in the non-governmental sector to the professional level. It was found that in practice, the non-governmental sector over the past four years has increased its potential as a provider of services to the state on market terms. Although they noted low activity among regional NGOs during the discussion of the basic document for them. This, in turn, raises the issue of communication support for the implementation of the Strategy, as well as raises the issue of the quality system of its monitoring and evaluation.
\end{abstract}

Citation: Dmytrenko Olena. (2020) Prospects of Institutional Development of the Non-Governmental Sector: Analysis of the Draft National Strategy for CSI Development. International Journal of Innovative Technologies in Social Science. 7(28). doi: 10.31435/rsglobal_ijitss/30122020/7232

Copyright: (C) 2020 Dmytrenko Olena. This is an open-access article distributed under the terms of the Creative Commons Attribution License (CC BY). The use, distribution or reproduction in other forums is permitted, provided the original author(s) or licensor are credited and that the original publication in this journal is cited, in accordance with accepted academic practice. No use, distribution or reproduction is permitted which does not comply with these terms.

Постановка проблеми. Наразі в Україні триває реалізація стратегії розвитку громадянського суспільства 2016-2020 років. Водночас Кабінет Міністрів України спільно 3 Інститутами громадянського суспільства вже працює над розробкою Національної стратегії із розвитку громадянського суспільства на 2021-2025 роки. Очікується, що цей документ буде прийнятий після проведення регіональних громадських обговорень та відповідного доопрацювання Стратегії.

Метою цієї статті $є$ аналіз проєкту Національної стратегії та оцінка ії потенційного впливу на інституціоналізацію неурядового сектору протягом найближчих п'яти років.

Матеріали та методи. На сьогодні досліджень конкретно цього документу ще не проведено, проте питаннями стратегічного курсу у розвитку ІГС опікуються багато вітчизняних дослідників та наукових інститутів. Зокрема, оцінці реалізації попереднього документа щорічно приділяють увагу науковці Національного інституту стратегічних досліджень, такі вчені як Яблонський B.M., Бекешкіна I.E., Гелетій М.M. та інші. Глобальні проблеми розвитку 
громадянського суспільства підіймають у своїх працях Г.І. Зеленько та А.Ф. Колодій. В останнє десятиріччя дослідженнями неурядового сектору цікавляться також органи центральної виконавчої влади. Так, для прикладу, Секретаріат Кабінету Міністрів України у 2019 році організував моніторингове дослідження імплементації Національної стратегії розвитку громадянського суспільства в Україні. Замовлення на це моніторингове дослідження отримала громадська організація «Лабораторія законодавчих ініціатив».

У даній роботі працювали більшою мірою із текстом проєкту Національної стратегії розвитку громадянського суспільства в Україні на 2021-2025 роки, а також 3 аналогічним документом, чинним на теперішній час (2016-2020 роки). Збір емпіричних даних здійснили із відкритих джерел провідних соціологічних українських установ в аспекті результатів опитування громадської думки. Інформацію про активність неурядових організацій у публічних закупівлях отримали за допомогою роботи в інформаційно-аналітичній системі моніторингу публічних закупівель bipro.prozorro.

Під час дослідження використали методи компаративного аналізу у частині дослідження змісту Стратегії та ії проєкту на наступні роки, метод включеного спостереження у частині аналізу залученості ІГС до процесу розробки стратегічного документа, а також метод структурно-функціонального аналізу для дослідження складових частин Стратегії у розрізі різних її аспектів.

Результати та обговорення. Специфічною особливістю останніх років стало все більше залучення організацій громадянського суспільства України до аналітичних досліджень у співпраці з органами влади та науковцями. Водночас збільшилась і кількість НУО, які спеціалізуються на аналітичній діяльності та проведенні оперативних досліджень. До того ж в тематичному спектрі досліджень, які проводять ІГС не останнє місце посідають питання інституціоналізації сектору, механізмів взаємодії з органами влади тощо. Тенденцію до збільшення кількості та якості роботи неурядових аналітичних центрів можемо прослідкувати також із результатів всесвітнього рейтингування аналітичних центрів Інститутом Лаудера. Для прикладу, ми прослідкували тенденцію до зміни рейтингу аналітичних центрів Центральної та Східної Європи протягом 2014-2019 років.

Таблиця 1. Українські аналітичні центри у рейтингу Інституту Лауреда

\begin{tabular}{|l|c|c|c|c|c|c|}
\hline $\begin{array}{l}\text { Рік } \\
\text { рейтингува } \\
\text { ння }\end{array}$ & $\begin{array}{c}\mathbf{2 0 1 4} \\
{[1, \text { с. 82] }}\end{array}$ & $\begin{array}{c}\mathbf{2 0 1 5} \\
{[2, \text { с. 68] }}\end{array}$ & $\begin{array}{c}\mathbf{2 0 1 6} \\
{[3, \text { с. 65] }}\end{array}$ & $\begin{array}{c}\mathbf{2 0 1 7} \\
{[4, \text { с. 86] }}\end{array}$ & $\begin{array}{c}\mathbf{2 0 1 8} \\
{[5, \text { c. 94] }}\end{array}$ & $\begin{array}{c}\mathbf{2 0 1 9} \\
{[6, \text { с. 100] }}\end{array}$ \\
\hline $\begin{array}{l}\text { Кількість } \\
\text { організацій }\end{array}$ & 3 & 8 & 8 & 9 & 9 & 9 \\
\hline 3 них НУО & 2 & 7 & 7 & 8 & 8 & 8 \\
\hline $\begin{array}{l}\text { Всього } \\
\text { установ в } \\
\text { рейтингу }\end{array}$ & $\mathbf{5 5}$ & $\mathbf{8 8}$ & $\mathbf{9 0}$ & $\mathbf{1 0 0}$ & $\mathbf{1 0 7}$ & $\mathbf{1 0 6}$ \\
\hline
\end{tabular}

Частка українських аналітичних центрів у регіональному рейтингу залишається низькою: від 5,4\% у 2014 році до $9 \%$ у 2017 році. Проте, абсолютна кількість організацій, які увійшли до рейтингу збільшується. Відтак, у порівнянні із показниками 2014 року у 2015-2016 роках приріст українських аналітичних центрів склав 62\%. Протягом 2017-2019 років - 66\%. При цьому, останні три роки кількість організацій, які потрапили до рейтингу залишається сталою - 9 установ. Ймовірніше за все це пов'язано зі зменшенням зацікавленості українських НУО у даному рейтингуванні, оскільки початковим кроком для оцінювання має бути заявка, подана претендентом. Іншим аспектом $є$ також поява багатьох альтернативних систем рейтингування та оцінки потенціалу НУО, відповідно організації можуть концентрувати свою увагу на рейтингах покладаючись на власні уподобання.

Одначе, збільшення кваліфікованих аналітичних центрів у неурядовому секторі після 2014 року відображає загальну тенденцію трансформації сектору на хвилі Революції Гідності. Таких же висновків дійшли автори аналітичної доповіді «Стан розвитку громадянського суспільства в Україні», спираючись на дослідження таких міжнародних організацій як Freedom 
House та USAID, а також результати підготовки індексу сталості неурядових організацій Творчим центром ТЦК. Так, на думку авторів доповіді за 2014 рік Україні вдалось повністю подолати відсторонення громадськості від процесу прийняття рішень, підвищилась активність ІГС та загальний рівень сталості сектору [7].

Повертаючись до питання розробки нової Національної стратегії розвитку громадянського суспільства, варто відзначити, що у документі розглядається ефективність та результативність роботи ІГС саме крізь призму партнерства із державою. На противагу попередньому документу, де основним акцентом залишалось забезпечення базових прав IГС та можливості їх долучення до процесу прийняття політичних рішень. На нашу думку, формат розробки нового стратегічного документа $є$ одним із показових прикладів вдалої співпраці держави, неурядового сектору та наукової спільноти. Хоча і активність регіональних ІГС у напрямку формування політик залишається під питанням. Основою для такого твердження став процес регіональних обговорень документу. Так, представлений Кабміном проєкт Стратегії протягом жовтня цього року має пройти ряд обговорень із представниками ІГС в усіх регіонах України. В одному із таких обговорень ми безпосередньо взяли участь. Загалом до нього долучились понад 60 учасників із трьох областей України. 3 огляду на епідеміологічну ситуацію в країні, обговорення проходили за допомогою електронних засобів комунікації в режимі онлайн. Тож, учасники мали можливість обговорити кожен розділ Стратегії детально. Для цього був використаний випадковий розподіл на невеликі групи. Неоднозначні висновки викликала активність ІГС під час даного заходу. Так, із 12 учасників групи, 9 протягом п’яти сесій жодного разу не долучились до дискусії. Тобто, 25\% потенційно зацікавлених НУО були готові тільки до пасивної форми участі. 3 чого ми зробили три припущення:

1. Більшість регіональних НУО недовіряють партнерству 3 органами влади та зосереджені на вирішенні локальних соціальних та інших проблем громад;

2. Для багатьох представників регіональних НУО все ще не притаманний посправжньому активістський тип політичної культури;

3. В середині сектору НУО також можливо провести поділ на активну меншість та пасивну більшість. В цьому випадку цікаво, що показник активності на одному з обговорень близький до показника бажання всього населення брати участь у діяльності ГО та обговоренні суспільно важливих питань. Так, згідно з загальнонаціональним опитуванням проведеним центром «Імідж-контроль» у 2018 році $2 / 3$ населення такого бажання не виявили. Зацікавленість активно брати участь в житті суспільства відмітили лише 33\% громадян [21].

Проте, однозначний висновок щодо кожного з описаних припущень потребує окремого дослідження. Тож підсумовуючи, відмітимо, що активність регіональних ІГС у розв'язанні стратегічних питань їх розвитку потребує більшої залученості представників цих ІГС на етапі розробки та планування. Зупинимось детальніше на змісті обговорюваного документа.

Загалом же нова Національна стратегія передбачає розвиток ІГС у чотирьох напрямках:

1. Створення сприятливих умов для формування та інституційного розвитку організацій (інститутів) громадянського суспільства.

2. Забезпечення ефективних процедур участі громадськості під час формування та реалізації державної, регіональної політики, вирішення питань місцевого значення.

3. Стимулювання участі інститутів громадянського суспільства в соціальноекономічному розвитку України.

4. Створення сприятливих умов для міжсекторальної співпраці [8].

Кожен із напрямків передбачає ряд завдань, а також відповідні очікувані результати, які мають бути досягнуті за підсумками реалізації стратегії. Стратегічні напрямки розвитку громадянського суспільства залишились незмінними відносно попереднього документа, розрахованого на 2016-2020 роки [9], хоча змістове наповнення завдань зазнало трансформації. Структурно документ розділений на чотири частини, описані вище, але для дослідження ми використали розподіл стратегічних завдань за метою та способами іiі досягнення. Тож, всі 87 задач та підзадач стратегії ми розподілили на чотири підгрупи:

- інформування та комунікація;

- удосконалення нормативно-правового забезпечення;

- організаційний розвиток та навчання;

- фінансування та фінансова спроможність. 
Класифікуючи завдання таким чином ми отримали наступні результати:

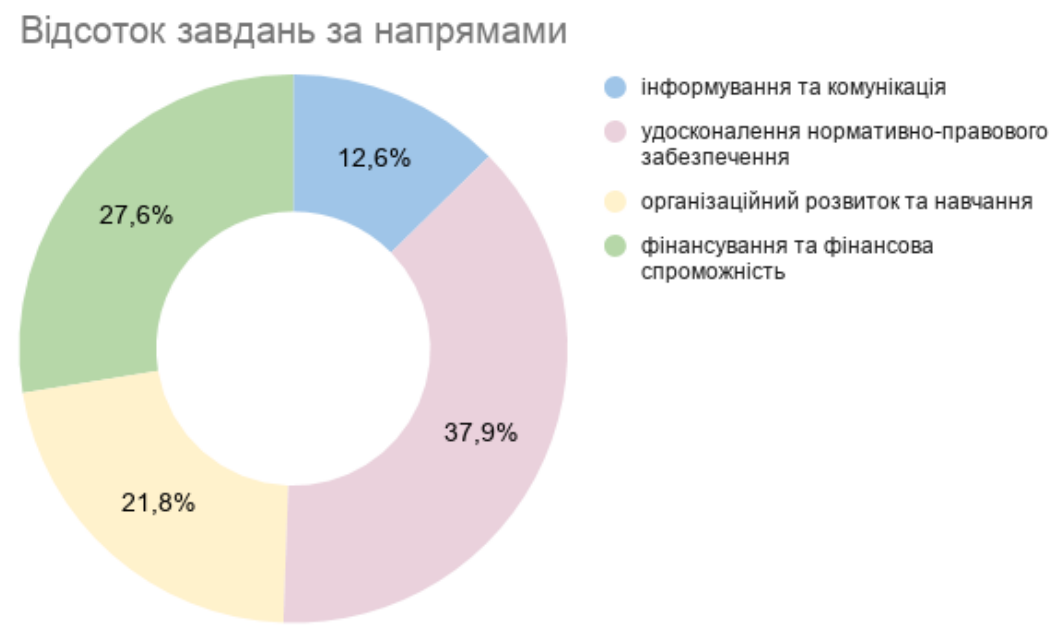

Діаграма 1. Розподіл завдань стратегї̈ за метою та характером ї̈ досягнення

Якщо заглибитись в аналіз виокремлених категорій, то варто зазначити, що 33 із 87 завдань направлені або витікають зі змін до чинних нормативно-правових актів або прийняття нових. Найбільша кількість нормативних змін зафіксована у стратегічному напрямку «Забезпечення ефективних процедур участі громадськості під час формування та реалізації державної, регіональної політики, вирішення питань місцевого значення». Більшість активностей планується сконцентрувати на удосконаленні механізмів локальної демократії та врегулюванні питань реалізації громадянами права на участь у суспільно-політичному житті громади та країни. Даний розділ орієнтований на роботу із територіальними громадами та пересічними громадянами, як складовою громадянського суспільства. Активності, якими наповнений розділ меншою мірою повпливають на розвиток сектору НУО. Відмітили також і те, що велика частка завдань Стратегії з удосконалення нормативно-правового забезпечення належить до виконання місцевими органами самоврядування, а не держави. Така особливість може дещо ускладнити реалізацію стратегії в регіонах, оскільки діяльність органів місцевого самоврядування $\epsilon$ достатньо самостійною. Згідно 3 законом України «Про місцеве самоврядування» питання регулювання інструментів локальної демократії належать до компетенції місцевих органів, Закон лише встановлює загальні правила та гарантії. Наприклад, п. 3. ст. 8 ЗУ «Про місцеве самоврядування» говорить: «Порядок проведення загальних зборів громадян за місцем проживання визначається законом та статутом територіальної громади» [10]. Водночас новий проєкт Стратегії містить завдання: «ухвалення законодавства, що регулюватиме порядок ініціювання та проведення загальних зборів жителів територіальних громад за місцем проживання та врахування їх рішень» [8]. Тобто, реалізувати дану задачу можливо шляхом розробки та прийняття комплексних статутів територіальних громад в Україні. Враховуючи їх самостійність та велику кількість на території країни, очевидно, що необхідна масштабна робота 3 кожною громадою, обмін досвідом, можливо налагодження менторства в мережі громад, оскільки лише нормативне врегулювання не вирішить питання такого характеру. Інший аспект роботи в напрямку удосконалення законодавства, що регулює діяльність громадянського суспільства це питання громадянської активності. Безперечно, правові механізми потребують адаптації до викликів сучасності, проте українське суспільство потребує також зрозумілої комунікації та залученості у процеси суспільно-політичного життя. Згідно 3 загальнонаціональним опитування, проведеного у серпні 2020 року Центром Разумкова, майже половина населення України $(45,5 \%)$ з усіх форм реалізації свого права на участь у суспільнополітичному житті надає перевагу голосуванню на виборах. Щодо інших форм участі в управлінні своєю громадою, то велика частина населення до неї не долучається, при цьому майже $30 \%$ громадян повідомляє про небажання брати участь у будь-яких подібних ініціативах.

При цьому можна побачити, що протягом останнього року бажання населення брати участь у таких активностях як діяльність громадських рад, громадські слухання, засіданнях органів місцевого самоврядування знизилась відносно аналогічних показників 2018 року. 
Таблиця 2. Готовність громадян до участі в управлінні своєю громадою [11], (\%)

\begin{tabular}{|c|c|c|c|c|}
\hline Вид участі & $\begin{array}{c}\text { Серпень } \\
2016\end{array}$ & $\begin{array}{c}\text { Червень } \\
2017\end{array}$ & $\begin{array}{c}\text { Серпень } \\
2018\end{array}$ & $\begin{array}{c}\text { Серпень } \\
\mathbf{2 0 2 0}\end{array}$ \\
\hline $\begin{array}{l}\text { Вибори до органів місцевого самоврядування в } \\
\text { якості кандидата }\end{array}$ & 4,5 & 13 & 8,6 & 12,3 \\
\hline $\begin{array}{l}\text { Вибори до органів місцевого самоврядування в } \\
\text { якості виборця }\end{array}$ & 29,2 & 41,7 & 46 & 45,2 \\
\hline Участь у громадських слуханнях & 17,1 & 18,9 & 16,3 & 10 \\
\hline $\begin{array}{l}\text { Участь у засіданнях органів місцевого } \\
\text { самоврядування }\end{array}$ & 9,1 & 13,3 & 10,3 & 6,5 \\
\hline $\begin{array}{l}\text { Участь у громадських організаціях, що } \\
\text { займаються проблемами місцевого } \\
\text { самоврядування }\end{array}$ & 8,9 & 11,9 & 10,8 & 8,3 \\
\hline $\begin{array}{l}\text { Участь у діяльності громадських рад при органах } \\
\text { влади }\end{array}$ & 5,7 & 8,7 & 8,2 & 6,7 \\
\hline Участь у вуличних акціях, пікетах, мітингах & 6,9 & 7,1 & 7,2 & 7,5 \\
\hline $\begin{array}{l}\text { Участь в органах самоорганізації населення } \\
\text { (будинкові, вуличні, квартальні комітети) }\end{array}$ & 10,4 & 13,7 & 7 & 11,4 \\
\hline Участь у громадських роботах з благоустрою & 24 & 15,4 & 16,6 & 20 \\
\hline $\begin{array}{l}\text { Участь як волонтера у різних видах громадської } \\
\text { допомоги (дитячим будинкам, багатодітнім } \\
\text { сім'ям, притулкам тощо) }\end{array}$ & 10,4 & 7,7 & 6,2 & 8,2 \\
\hline Надання фінансових пожертв на потреби громади & 4 & 2 & 1,8 & 2,8 \\
\hline Інше & 0,4 & 0,3 & 0,1 & 1,1 \\
\hline $\begin{array}{l}\text { Не готовий брати участь у жодній з цих форм } \\
\text { діяльності }\end{array}$ & 35,3 & 30,3 & 29,2 & 28,5 \\
\hline Важко сказати & 11,4 & 8,3 & 6,8 & 6 \\
\hline
\end{tabular}

На противагу, за даними іншого соціологічного опитування, проведеного Фондом демократичних ініціатив ім. Ілька Кучеріва, кожен п'ятий українець фінансово підтримує діяльність громадських та/або благодійних організацій [12]. 3 чого припускаємо, що великою залишається частка населення, яке опікується проблемами свого населеного пункту та держави, але самостійно не має бажання працювати над їх розв'язанням, натомість готові в цьому підтримати НУО, яким довіряють.

Тож, окрім нормативного аспекту забезпечення ефективних процедур участі громадськості у процесі прийняття рішень одна із перших потреб це активізація громад. Проєкт стратегії передбачає такі активності, але у загальному підрахунку, завдання спрямовані на інформування та комунікацію становлять більш ніж 1/8. При цьому завдання 3 інформування входять до всіх чотирьох стратегічних напрямків. Розуміючи, що в даному питанні ефективність комунікації не залежить від кількості задач з інформування, вважаємо за доцільне розглянути можливість створення додатку до дорожньої карти, розробка якої є наступним етапом у втіленні стратегії, комунікаційного компонента окремо. Таку необхідність можна аргументувати:

- по-перше, неоднорідністю населення країни, різним рівнем громадської свідомості та доступу до інформації;

- по-друге, великою кількістю комунікаторів на тему громадянського суспільства загалом та діяльності НУО зокрема.

Комунікаційний компонент в такому випадку може змінити узагальнене формулювання «налагодження інформування» на чітке та зрозуміле для виконання завдання. Наявність комунікаційних стратегій наразі не рідкість як для організацій громадянського суспільства, так і для органів влади. Так, наприклад, власні комунікаційні стратегії мають Міністерства та ВРУ. У документі останньої підвищення активності громадян визначено однією з основних іiі цілей [13]. Розробка такого документу спільно із розробкою дорожньої карти реалізації Стратегії 
допоможе окреслити цільову аудиторію, підібрати зручні способи комунікації за зрозумілі для населення повідомлення. 3 огляду на те, що багато ЦОВВ та ВРУ вже мають власні плани із комунікації, цей документа має стати компліментарним до них, адже бенефіціарами в усіх випадках буде залишатись громадянське суспільство.

Третя підгрупа завдань, яку ми виокремили - «організаційний розвиток та навчання». До цієї категорії віднесли активності, які передбачають розширення можливостей організацій громадянського суспільства посилити свою роль в державі через розбудову інфраструктури, експертного потенціалу та поліпшення фахових навичок. Завдання цього напрямку більшою мірою орієнтовані на вже сформовані громадські структури і мають забезпечити допоміжну функцію у їх розвитку. Таких активностей ми виділили 19, проте серед них є комплексне завдання, реалізація кого може вплинути на трансформацію свідомості громадян та започаткувати в масовій культурі новий ціннісний орієнтир. Це стратегічне завдання із розвитку волонтерської діяльності. Разом із нормативним та фінансовим аспектами, Стратегія передбачає роботу із популяризації та навчання волонтерській діяльності починаючи із закладів середньої освіти, де найважливіше це дозвіл дітям із 12 років займатись волонтерською діяльністю. Згідно 3 дослідженнями мотивів волонтерства, така діяльність не лише позитивно впливає на сферу в якій проводиться, а також і на формування особистостей самих волонтерів. Так, наприклад, Л.І. Матвієнко, К.С. Алексейченко у своєму дослідженні ціннісно-мотиваційного аспекту волонтерства приходять до висновку, що серед людей, які займаються волонтерською діяльністю більший відсоток цілеспрямованих громадян, а їх рівень задоволеності власним життям вищий у порівнянні з тими, хто таку діяльність не веде [14]. Окрім цього, позитивно налаштовані до волонтерів і громадяни України в цілому. Як свідчить дослідження соціологічної групи «Рейтинг» станом на кінець 2019 року рівень довіри до волонтерів в Україні становив 69\%. Це найвищий результат довіри серед усіх інститутів, які були представлені в опитуванні [15]. Тож інституціоналізація феномену волонтерства в найближчі п'ять років залишатиметься актуальною. До того ж такий вид діяльності є активним, i навіть не залучаючи громадян до процесу прийняття політичних рішень може підвищити їх активність у соціальному житті свої громади. Решта завдань цього напрямку $є$ не такими фундаментальними, проте не менш важливими. Загалом напрямок організаційного розвитку та навчання варто відзначити тим, що на відміну від решти, його завдання вимагають включеності неурядових організацій. Тобто, в цьому випадку передбачається не просто про надання можливостей чи забезпечення доступу ІГС до цих можливостей, а також і відповідна діяльність 3 боку ІГС. Це і питання доброчесності і прозорості самих ІГС і підвищення фаховості та галузевої експертизи представників ІГС, у тому числі із використанням методів формальної освіти i створення умов для професійної зайнятості населення в роботі ІГС [8]. На нашу думку, це одні із ключових завдань Стратегії, які дозволять зберегти баланс між розвитком галузі на державному рівні та його розбудовою з боку ІГС. Такого висновку дійшли через те, що аби скористатися можливостями з організаційного розвитку та навчань, ІГС мають бути безпосередньо зацікавлені у такій роботі та використовувати інструменти, які для них стануть ще більш доступними.

Остання підгрупа завдань, яку ми виділили та розглянемо в рамках аналізу Стратегії це фінансування та фінансова спроможність. Цей напрямок $\epsilon$ визначальним у питанні існування та функціонування сектору НУО зокрема та ІГС в цілому. Якщо в минулому фінансування діяльності неурядового сектору більшою мірою здійснювали міжнародні донорські організації за коштом грантових надходжень, то на сьогодні діяльність НУО все більше концентрується у напрямку обслуговування населення, надання послуг (наприклад аналітичних) для органів самоврядування тощо. Наразі неурядовий сектор кристалізується у повноправного економічного гравця, який на рівні із сектором держави та бізнесу може впливати на соціально-економічний розвиток країни. Звичайно, що НУО працюють як некомерційні організації, метою їх діяльності не $\epsilon$ отримання прибутку. Це зокрема передбачено українським податковим законодавством [16]. Проте ці організації мають право на здійснення господарської діяльності, якщо дохід від неї спрямовується на статутну діяльність організацій [17]. Більшість ІГС не маючи постійних джерел фінансування змушені залучати для реалізації своїх функцій грантові та бюджетні кошти, членські внески використовуючи для цього різні механізми. В суспільстві питання про те хто має фінансувати діяльність неурядових (зокрема громадських) організацій досі $є$ дискутовним. Проте, ми розуміємо, що всі послуги або продукти, які створюють НУО для громад мають свою собівартість, тож відповідно не можуть створюватись без залучення ресурсів. Питання надання IГC безперешкодного доступу до інструментів залучення коштів знайшло свій відбиток ще у попередній Стратегії. 
Зокрема серед іiі завдань передбачався розвиток соціального підприємництва, запровадження практики участі НУО в публічних закупівлях тощо [9]. У проєкті нової Стратегії питання фінансування ІГС окреслене масштабно. На нього припадає 27,6\% від усіх завдань Стратегії. Така необхідність обумовлена розвитком ринку послуг, які надають неурядові організації та підвищення конкуренції серед них, зокрема і в аспекті якості. Про це свідчить і збільшення кількості НУО, які виходять у площину публічних закупівель як учасники і підвищення прозорості проведення соціального замовлення і поширення практики громадського бюджету у регіонах. За даними дослідження Європейського простору станом на 2019 рік такий інструмент як бюджет участі використовували у 200 населених пунктах країни [18], що є однозначно позитивним показником, оскільки свідчить про те, що такий механізм набирає популярності й серед органів влади на місцях.

Статистика участі неурядових організацій у публічних закупівлях також свідчить про підвищення зацікавленості організацій у використання такого інструменту залучення коштів для здійснення своєї діяльності. Ми проаналізували статистику участі ІГС на прикладі організаційноправової форми «ГО» у закупівлях за бюджетні кошти протягом останніх 4-х років.

Таблиця 3. Участь ГО у публічних закупівлях [19]

\begin{tabular}{|c|c|c|}
\hline Рік & Кількість учасників всього & Кількість учасників ГО \\
\hline 2017 & 127645 & 138 \\
\hline 2018 & 148173 & 230 \\
\hline 2019 & 159963 & 275 \\
\hline 2020 & 208539 & 364 \\
\hline
\end{tabular}

Відтак, можемо спостерігати, що від загальної кількості учасників неурядові організації досі займають малу частину, проте приріст їх кількості у системі закупівель щороку збільшується. За 10 місяців 2020 року в закупівлях вже взяли участь майже вдвічі більше ГО ніж за весь 2017 рік.

В цьому завдання Стратегії наслідують тенденцію розвитку ІГС в аспекті нарощення фінансової спроможності. Водночас велика увага в документі приділяється не лише поліпшенню навичок ІГС в опановуванні інструментів залучення коштів, але й організації системи підтримки розвитку громадянського суспільства. Зокрема, планується започаткувати відсотковий механізм підтримки ІГС за прикладом такої системи у країнах $€ C$, створити податкові стимули для громадян та бізнесу у підтримці IГC та благодійної діяльності, а також запровадити підтримку інституційного (організаційного) розвитку організацій [8].

Попри те, що Стратегія передбачає велику кількість завдань, спрямовану на розв'язання проблем фінансування ІГС, питання фінансового забезпечення реалізації самої Стратегії чіткого плану не має. Проєкт передбачає можливість фінансування реалізації стратегії коштом Державного бюджету, місцевих бюджетів, міжнародної технічної допомоги та інших джерел не заборонених законодавством. Документ передбачає також створення державного інструменту для фінансування ІГС, проте схожий захід вже планувався в рамках реалізації Стратегії 20162020 років у вигляді фонду розвитку громадянського суспільства. Проте станом на сьогодні у Державному бюджеті України такого фонду не передбачено. Водночас, практика такого інструменту є доволі поширеною серед країн Європи. Наприклад, у таких країнах як Хорватія та Угорщина існують Національні фонди підтримки громадянського суспільства. Їх фінансування не завжди здійснюється безпосередньо із бюджету країни, проте механізми їх наповнення є сталими (наприклад фінансування коштом від виграшів лотереї) [20].

Висновки. Підбиваючи підсумок аналізу проєкту Стратегії розвитку громадянського суспільства в Україні підкреслимо, що документ має на меті амбітні завдання. Громадянське суспільство цьогоріч є активно залученим гравцем до розробки даного документу. Обговорення робочої версії документу проводилось у кожному регіоні України, тож за результатами доопрацювання проєкту та врахування пропозицій від ІГС цей документ має стати комплексним спільним баченням держави та неурядового сектору майбутнього інститутів громадянського суспільства України. Залучення до розробки всіх зацікавлених сторін також має позитивно вплинути на виконання завдань стратегії та спільну діяльність впродовж наступних п'яти років. Поряд із чим, маємо акцентувати увагу на таких питаннях як необхідність розробки якісної 
системи моніторингу та оцінки, оскільки успішність та ефективність реалізації тих чи інших завдань потребує підтвердження та верифікації. Актуальне також і питання контролю виконання. Наразі документ не містить календарю звітності, проте підбивання підсумків та оцінка результативності має здійснюватись регулярно. Доцільно також розглянути можливість проміжного звітування частіше, ніж під час реалізації Стратегії попередніх років. Це пов'язано в першу чергу з оперативністю та гнучкістю роботи неурядових організацій, які здатні реагувати на виклики дещо швидше, ніж державні структури. Тож зі зміною контексту не втрачатиметься час на аналіз ситуації та вироблення рішень.

Наскрізним питанням реалізації стратегії та партнерства держави та НУО в цілому залишається також комунікація між ними та назовні. Цей аспект доцільно врегулювати у спільній комунікаційній стратегії. Це не лише спростить діалог та підвищить якість заходів 3 інформування населення, але й також позитивно позначиться на ставленні населення та його довірі до обох сторін.

\section{ЛIТЕРАТУРА}

1. McGann, James G., "2014 Global Go To Think Tank Index Report" (2015). TTCSP Global Go To Think Tank Index Reports. 8. University of Pennsylvania Philadelphia, PA http://repository.upenn.edu/think_tanks/8

2. McGann, James G., "2015 Global Go To Think Tank Index Report" (2016). TTCSP Global Go To Think Tank Index Reports. Paper 10. University of Pennsylvania Philadelphia, PA http://repository.upenn.edu/think_tanks/10

3. McGann, James G., "2016 Global Go To Think Tank Index Report" (2017). TTCSP Global Go To Think Tank Index Reports. 12. University of Pennsylvania Philadelphia, PA http://repository.upenn.edu/think_tanks/12.

4. McGann, James G., "2017 Global Go To Think Tank Index Report" (2018). TTCSP Global Go To Think Tank Index Reports. 13. University of Pennsylvania Philadelphia, PA https://repository.upenn.edu/think_tanks/13

5. McGann, James G "2018 Global Go To Think Tank Index Report" (2019). TTCSP Global Go To Think Tank Index Reports. 16. University of Pennsylvania Philadelphia, PA https://repository.upenn.edu/think_tanks/16

6. McGann, James G "2019 Global Go To Think Tank Index Report" (2020). TTCSP Global Go To Think Tank Index Reports. 17. University of Pennsylvania Philadelphia, PA https://repository.upenn.edu/think_tanks/17

7. Yablonsky V., Voznyuk P., Gorelov D. [etc.]; ed. Kornievsky O. Rozymnyy M. (2015). Development of civil society in Ukraine, Kyiv, Ukraine: NISS https://niss.gov.ua/sites/default/files/201511/Korniyevskiy_12_11-58701.pdf

8. Draft of National strategy for promoting the development of civil society in Ukraine (2020) Retrieved from https://www.kmu.gov.ua/news/zaproshuyemo-do-obgovorennya-proektu-novoyi-nacionalnoyi-strategiyispriyannya-rozvitku-gromadyanskogo-suspilstva-v-ukrayini

9. On promoting the development of civil society in Ukraine Decree of President of Ukraine № 68 (2016) Retrieved from https://zakon.rada.gov.ua/laws/show/ru/68/2016?lang=en\#Text

10. On Local-Self Government in Ukrine Law № 280/97-BP (revision 2020) Retrieved from https://zakon.rada.gov.ua/laws/show/280/97-\%D0\%B2\%D1\%80?lang=en\#Text

11. Sociological research «Public opinion on decentralization reform and its results» (2020) Retrieved from https://razumkov.org.ua/napriamky/sotsiologichni-doslidzhennia/gromadska-dumka-naselennia-shchodoreformy-detsentralizatsii-ta-ii-rezultativ-serpen-2020r

12. Sociological research «Public opinion polls to assess changes in citizens' awareness of NGOs and their activities» (2020) Retrieved from https://dif.org.ua/en/article/dopomozhi-sobi-sam-ukraintsi-rozcharovaniv-reformakh-ale-gotovi-pidtrimuvati-odne-odnogo-ta-svoi-gromadi

13. Communication strategy of the Verkhovna Rada of Ukraine 2017-2021 Retrieved from https://iportal.rada.gov.ua/uploads/documents/44841.pdf

14. Matviienko, L.I., Aleksejchenko, K.S. (2016) «The personality of volunteers in psychological dimension: Value-motivational aspect (Provision of social services to vulnerable groups)» Labor market and employment, 1, 51-59. http://ipk.edu.ua/wp-content/uploads/2019/09/1-20161.pdf

15. Sociological research "Assessment of the situation in Ukraine» (2019) Retrieved from http://ratinggroup.ua/files/ratinggroup/reg_files/rg_ukraine_102019_press.pdf

16. Tax Code of Ukraine (revision 2020) Retrieved from https://zakon.rada.gov.ua/laws/show/275517?lang=en\#Text

17. Explanation of the State Fiscal Service «Non-profit organizations and their economic activity» (2014) Retrieved from http://tr.sfs.gov.ua/media-ark/news-ark/print-148675.html

18. Analytical research «Public funding of NGO's: the main changes in the first half of 2019» (2019) Retrieved from https://euprostir.org.ua/stories/142754

19. Information and analytical system for monitoring procurement data Retrieved from https://bi.prozorro.org/

20. Analytical article «Sources of funding for NGOs: European and Ukrainian experience» (2015) Retrieved from https://rozvytok-hromady.com/po-suti/djerela-finansuvannia-hromadskyx-orhanizacii-ievropeiskyi-taukrainskyi-dosvid

21. Sociological research «The tendency of Ukrainian citizens to participate in the discussion and solution of public problems» Bauman Y. (2019) Retrieved from https://imcon.com.ua/bauman-yu-skhilnist-gromadyan-ukraini/ 